\title{
SISTEM PRESENSI ONLINE DAN POIN HUKUMAN DI SMK MAA'ARIF NU O4 PAKIS BERBASIS WEB
}

\author{
Dwi Safiroh Utsalina ${ }^{1)}$, Andri Prasetyo ${ }^{2)}$ \\ ${ }^{1,2}$ Program Studi Sistem Informasi, STMIK Pradnya Paramita \\ Email: utsalina@stimata.ac.id ${ }^{1)}$ \\ Nomor Telp : +62 82132292264 \\ Asal Negara: Indonesia
}

\begin{abstract}
ABSTRAK
Kehadiran siswa di sekolah, merupakan salah satu komponen yang penting dalam proses pembelajaran. Sering hadir di kelas dan mengikuti pembelajaran dapat mempengaruhi tingkat pemahaman siswa pada pelajaran yang diberikan. Aktif mengikuti pembelajaran di kelas juga menjadi salah satu tolak ukur penilaian kedisiplinan seorang siswa. Namun proses pencatatan kehadiran siswa pada SMK Ma'arif NU 04 masih dilakukan secara manual, yaitu setiap siswa yang hadir di sekolah/ kelas harus menuliskan nama lengkap dan tandatangan di atas kertas yang telah disiapkan oleh bagian administrasi sekolah. Hal tersebut membuat proses presensi dan pemberian poin hukuman membutuhkan waktu yang lebih lama dan data yang dihasilkan tidak akurat, selain itu cara ini juga rawan kehilangan data siswa. Dengan metode pencatatan kehadiran secara manual ini juga mengakibatkan tidak sinkronnya data dalam pembuatan laporan akhir pembelajaran, baik harian, mingguan dan bulanan. Penelitian ini menghasilkan sebuah sistem presensi online yang menggunakan MySQL untuk penyimpanan datanya. Diketahui dari hasil pengujian bahwa terdapat peningkatan efisiensi waktu pada aktivitas pencatatan kehadiran siswa dan dapat menentukan poin hukuman yang diberikan kepada siswa sebesar 4.6\%, sehingga dapat pula mengefisiensikan waktu yang dibutuhkan oleh admin yang ada di SMK berkaitan dengan mengelola data.
\end{abstract}

\section{Kata kunci: Sistem Presensi Online, Poin Hukuman, Kehadiran, Siswa}

\section{ABSTRACT}

One of the most significant aspects of the learning process is the presence of students in schools (Educational Institutions). Frequent attendance in class and participation in learning can have an impact on the students' understanding level of the lessons taught. In addition, one of the criteria for evaluating a student's discipline is active participation in classroom instruction. However, the process of documenting student attendance is still done manually, with each student writing his name and signature on paper prepared by the school administration. As a result of these circumstances, the attendance process and the awarding of penalty points are lengthy and imprecise, and this system is also prone to data loss. This method of manually recording attendance results in asynchronous data in the final learning report, which is produced daily, weekly, and monthly. This research develops in an online presence system that stores data in MySQL. According to the test results, there is a gain in time efficiency in student attendance recording activities, and it can determine the penalty points issued to students (4.6 percent), so it can also simplify the tie needed by admins in SMK linked to data management.

\section{Keywords: Attendance, online attendance system, penalty points, students}

\section{PENDAHULUAN}

Keberhasilan suatu lembaga pendidikan tidak hanya dilihat dari prestasi akademik dan non akademik saja, namun juga dilihat dari presensi (kehadiran) siswa di lembaga pendidikan sebagai parameter Kedisiplinan(Susanto \& Sudiyatno, 2014). Kehadiran siswa di lembaga pendidikan atau sekolah menjadi salah satu syarat untuk mengikuti ujian yang diselenggarakan di akhir semester. Presensi atau pencatatan kehadiran siswa di sekolah digunakan sebagai salah satu penilaian dalam proses pembelajaran, karena dengan intensitas kehadiran yang tinggi berbanding lurus dengan tingginya tingkat pemahaman siswa terhadap pelajaran yang disampaikan (Fitrah et al., 2021) oleh guru dan parameter menilai keseriusan siswa dalam mengikuti kegiatan pembelajaran. Pencatatan kehadiran sebagai tolok ukur keaktifan siswa (Ardianti, 2019) juga diterapkan oleh SMK Ma'arif NU, yaitu sebuah sekolah yang bertempat disebuah kabupaten di kota Malang Propinsi Jawa Timur.SMK Ma'arif NU ini merupakan sekolah swasta yang berupaya mengembangkan diri, namun perkembangan yang dilakukan hanya seputar pemenuhan fasilitas fisik. Sedangkan pengembangan sistem, sebagai peningkatan kinerja pengelolaan lembaga belum dilakukan oleh sekolah yang bersangkutan, sehingga siswa masih harus menuliskan data diri, yang terdiri dari Nomor Induk Siswa (NIS), nama lengkap siswa, Kelas dan tanda tangan diatas kertas. Hal tersebut 
mengakibatkan kurang efisiennya aktivitas pencatatan kehadiran siswa, dan pada penerapannya terdapat siswa yang melakukan kecurangan dengan mengisikan data dari teman sekelasnya yang sedang tidak hadir dikelas. Hal ini mengakibatkan pihak pengelola data siswa (admin sekolah) mendapatkan data yang tidak akurat. Sedangkan data tersebut akan digunakan sebagai pendukung dalam menentukan poin hukuman bagi siswa, sehingga pemberian poin hukuman sering tidak tepat sasaran, dan kesalahan tersebut mengakibatkan ketidaknyamanan bagi siswa yang disiplin.

Penggunaan sistem berbasis web dalam mengelola sebuah sistem memiliki beberapa kelebihan dibanding desktop, seperti yang disampaikan oleh (Adani, 2018) dalam artikelnya, hal ini juga berlaku pada bagian pengelola data (admin) yang dapat melakukan aktivitasnya dalam membuat laporan kehadiran siswa dimana saja.

Berdasarkan uraian pada paragraf sebelumnya, seputar permasalahan yang dihadapi oleh pihak sekolah karena belum adanya sistem terkomputerisasi berupa sistem pencatatan kehadiran siswa, oleh karena itu pada penelitian ini perlu membuat Sistem Presensi Online dan Poin Hukuman bagi siswa SMK Ma'arif NU 04 Pakis berbasis Web.

\section{Metode Penelitian}

Pada penelitian yang dilaksanakan pada SMK Ma'arif NU 04 Pakis dengan menggunakan metode ini akan dimulai dengan identifikasi masalah, fase ini diharap dapat mengetahui kebutuhan dari objek penelitian, tahapan berikutnya mengumpulkan data berupa waktu yang diperlukan untuk mencatat kehadiran siswa, memberi poin hukuman dan membuat laporan seputar keaktifan siswa.

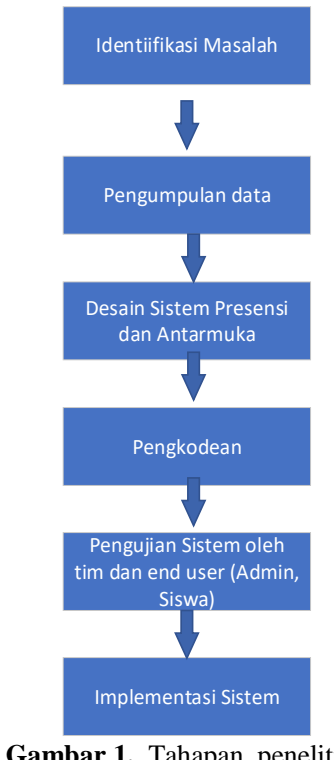

Tahapan selanjutnya adalah perancangan (desain). Pada pembuatan sistem presensi online ini menggunakan metode pengembangan perangkat lunak yang disebut Waterfall, metode ini dikenal sistematis karena dijalankan secara berurutan mulai dari identifikasi kebutuhan (Requirements) sampai dengan Maintenance. Setelah mengetahui kebutuhan dari penelitian, tahap berikutnya adalah merancang sistem yang diusulkan yaitu sistem presensi online terlihat pada Gambar 2.

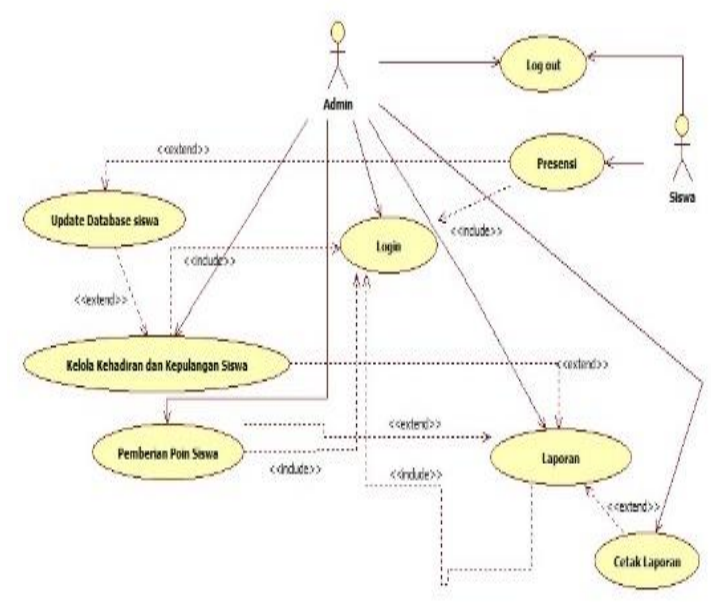

Gambar 2. Use case diagram sistem presensi online

\subsection{Use Case Diagram}

Pada desain sistem yang terdapat pada Gambar 2 tersebut terdiri dari beberapa Aktor, yaitu Admin (pengelola data presensi online dan mencetak laporan presensi disetiap bulan yang ada di sekolah) dan Siswa, Aktor Siswa sebagai pengguna sistem presensi online yang menginputkan datanya untuk kemudian digunakan sebagai pendukung pembuatan laporan kehadiran siswa pada tiap bulan, dimana kedua actor harus melakukan login terlebih dahulu ke sistem. Pengelolaan data siswa merupakan perilaku sistem, dimana admin melakukan create, read, update dan delete. Aktivitas pemberian poin kepada siswa disesuaikan dengan ketetapan admin.

\subsection{Activity Diagram}

Beberapa aktivitas yang terjadi pada sistem ditampilkan secara berurutan mulai Gambar 3 sampai dengan 6. Activity Diagram 3 menggambarkan aktifitas Login, yang dimulai dari Aktor yang terdiri dari Admin dan Siswa saat menjalankan program, disertai dengan pesan baik berhasil maupun gagal. Pada Gambar 4 menunjukkan Activity Diagram kelola Kehadiran Siswa. Pada aktivitas ini Dimulai dengan Admin yang memilih menu tambah yang dilanjutkan dengan munculnya data siswa. setelah Admin berhasil menginputkan data siswa yang ditandai dengan pesan "data berhasil tersimpan". Sedangkan saat Admin memilih menu Edit maka akan muncul form edit data, setelah selesai actor mengklik Siswa menjalankan program, dan dilanjutkan dengan login pada sistem, apabila Siswa sukses login maka akan muncul pesan "anda telah login", sebaliknya akan muncul pesan "silahkan login kembali" kemudian actor harus mengulang. 


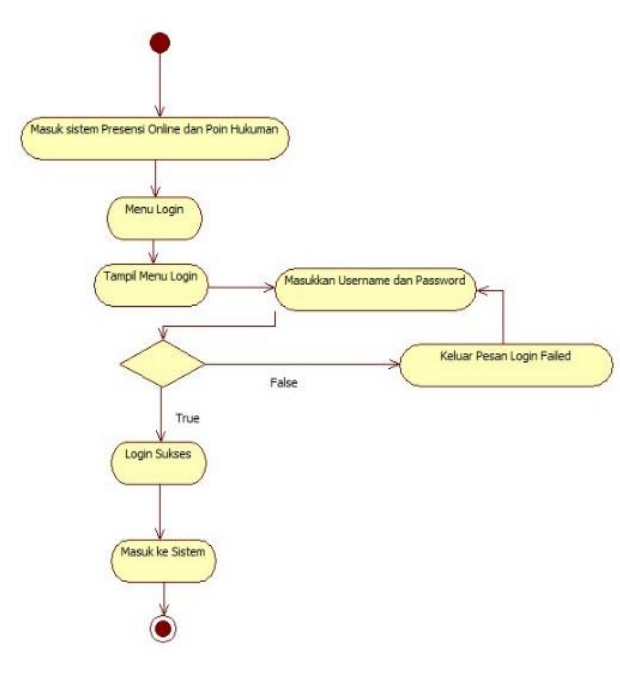

Gambar 3. Activity diagram login

Aktivitas berikutnya terdapat pada Gambar 5 yaitu Activity diagram Pemberian Poin. Setelah Admin membuka form tambah,(create) dan menginputkan data siswa, selanjutnya Admin juga dapat mengedit identitas siswa melalui form edit.

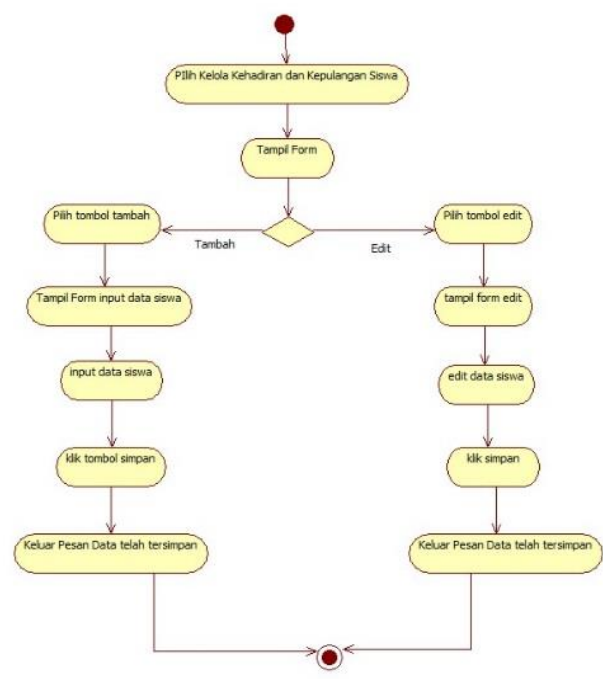

Gambar 4. Activity diagram kelola kehadiran

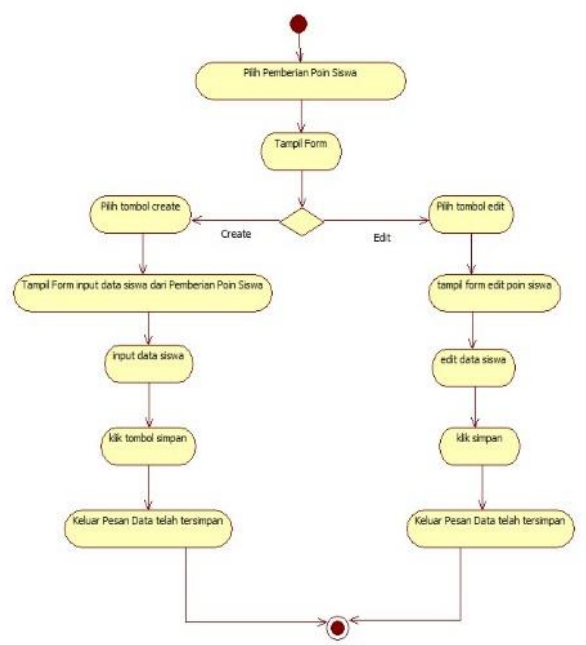

Gambar 5. Activity diagram pemberian poin siswa
Activity Diagram Pembuatan laporan oleh Admin terlihat pada gambar 6 , didasarkan oleh data dan informasi yang diperoleh dari aktivitas kelola Kehadiran dan jam Pulang Siswa serta pemberian poin siswa.

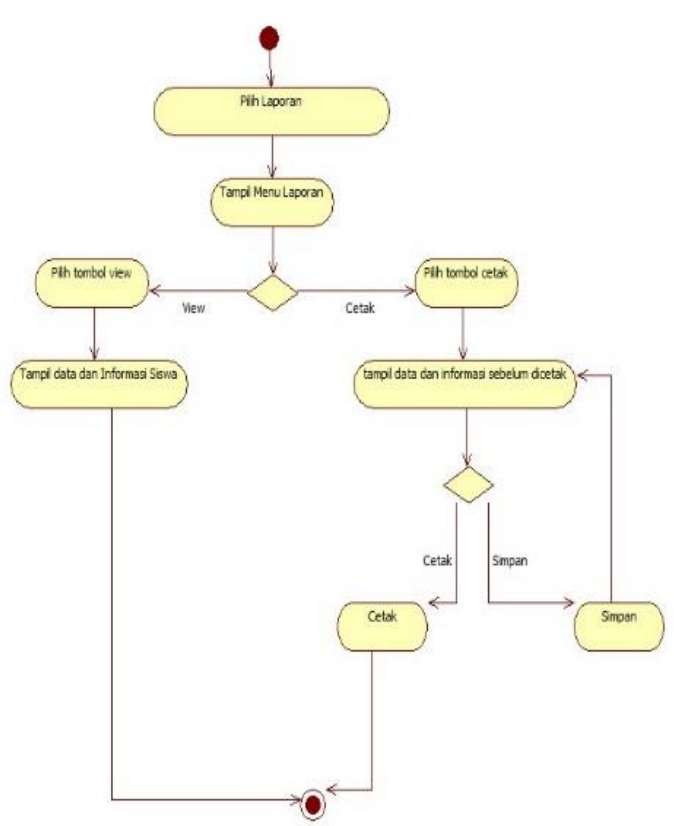

Gambar 6. Activity diagram laporan

\subsection{Pengujian}

Tahapan pengujian pada penelitian ini menggunakan konsep Black Box bagi admin dan siswa(Haryono \& Asa Firdausi, 2017), yaitu pengujian yang dikhususkan pada fungsional requirements, yaitu menguji kesesuaian antara kebutuhan sistem (Software requirements) dengan kondisi perangkat lunak yang ada. Hasil pengujian menunjukkan bahwa sistem telah bekerja dengan apa yang diharapkan(Afrianto \& Setiyadi, 2019).

\section{HASIL DAN PEMBAHASAN}

Pada penelitian ini menggunakan pengujian dengan metode black Box. Dalam rangka mengetahui perilaku dari sistem secara fungsionalitas(Mursyidah \& Hidayat, 2018)

Terdapat beberapa pengujian sistem yang diterapkan untuk mengetahui error pada sistem(Setiyani, 2019) dan (Hanifah et al., 2016) sebagai berikut : 


\subsection{Pengujian sistem pada Admin dan Siswa}

Tabel 1. Pengujian login siswa dan Admin

\begin{tabular}{|c|c|c|c|c|c|}
\hline \multirow[b]{2}{*}{ No } & \multicolumn{2}{|c|}{ Data Masukan } & \multirow[b]{2}{*}{ Yang Diharapkan } & \multirow[b]{2}{*}{ Hasil Pengujian } & \multirow[b]{2}{*}{ Kesimpulan } \\
\hline & Variabel & Masukan & & & \\
\hline \multirow[t]{2}{*}{1.} & Username & Kosong & \multirow[t]{2}{*}{ gagal } & \multirow[t]{2}{*}{ gagal } & \multirow[t]{2}{*}{ Pengujian sukses } \\
\hline & Password & Kosong & & & \\
\hline \multirow[t]{2}{*}{2.} & Username & User & \multirow[t]{2}{*}{ gagal } & \multirow[t]{2}{*}{ gagal } & \multirow[t]{2}{*}{ Pengujian sukses } \\
\hline & Password & Kosong & & & \\
\hline \multirow[t]{2}{*}{3.} & Username & Kosong & \multirow[t]{2}{*}{ gagal } & \multirow[t]{2}{*}{ gagal } & \multirow[t]{2}{*}{ Pengujian sukses } \\
\hline & Password & User123 & & & \\
\hline \multirow{2}{*}{4.} & Username & Kosong & \multirow{2}{*}{ gagal } & \multirow{2}{*}{ gagal } & \multirow{2}{*}{ Pengujian sukses } \\
\hline & Password & Admin 123 & & & \\
\hline \multirow{2}{*}{5.} & Username & User & \multirow{2}{*}{ berhasil } & \multirow{2}{*}{ berhasil } & \multirow{2}{*}{ Pengujian sukses } \\
\hline & Password & User123 & & & \\
\hline \multirow{3}{*}{6.} & Username & Admin & \multirow{2}{*}{ berhasil } & \multirow{2}{*}{ berhasil } & \multirow{2}{*}{ Pengujian sukses } \\
\hline & Password & Admin 123 & & & \\
\hline & & & & us pengujian login & Sukses $100 \%$ \\
\hline
\end{tabular}

Tabel 2. Pengujian input, edit dan delete data siswa

\begin{tabular}{|c|c|c|c|c|c|}
\hline \multirow{2}{*}{ No } & \multicolumn{2}{|c|}{ Data Masukan } & \multirow{2}{*}{ Yang Diharapkan } & \multirow{2}{*}{ Hasil Pengujian } & \multirow{2}{*}{ Kesimpulan } \\
\hline & Variabel & Masukan & & & \\
\hline 1. & $\begin{array}{l}\text { NIS } \\
\text { Nama lengkap } \\
\text { Password } \\
\text { Kelas } \\
\text { Alamat }\end{array}$ & $\begin{array}{l}\text { Kosong } \\
\text { baru } \\
\text { baru } \\
\text { XII TKJ } \\
\text { baru }\end{array}$ & $\begin{array}{l}\text { Gagal menyimpan data } \\
\text { baru }\end{array}$ & Penyimpanan gagal & Pengujian berhasil \\
\hline 2. & $\begin{array}{l}\text { NIS } \\
\text { Nama lengkap } \\
\text { Password } \\
\text { Kelas } \\
\text { Alamat }\end{array}$ & $\begin{array}{l}1990121 \\
\text { baru } \\
\text { baru } \\
\text { XII TKJ } \\
\text { baru }\end{array}$ & $\begin{array}{l}\text { Sukses menyimpan } \\
\text { data baru }\end{array}$ & Penyimpanan sukses & Pengujian berhasil \\
\hline 3. & $\begin{array}{l}\text { NIS } \\
\text { Nama lengkap } \\
\text { Password } \\
\text { Kelas } \\
\text { Alamat } \\
\end{array}$ & $\begin{array}{l}1990121 \\
\text { Baru diganti } \\
\text { Baru } \\
\text { XII TKJ } \\
\text { baru }\end{array}$ & $\begin{array}{l}\text { Sukses menyimpan } \\
\text { data yang diedit }\end{array}$ & Penyimpanan sukses & Pengujian sukses \\
\hline \multirow[t]{2}{*}{4.} & $\begin{array}{l}\text { NIS } \\
\text { Nama lengkap } \\
\text { Password } \\
\text { Kelas } \\
\text { Alamat } \\
\end{array}$ & $\begin{array}{l}1990121 \\
\text { Baru diganti } \\
\text { Baru } 002 \\
\text { XII TKJ } \\
\text { baru }\end{array}$ & $\begin{array}{l}\text { Sukses menghapus } \\
\text { data }\end{array}$ & Hapus data sukses & Pengujian sukses \\
\hline & & & & $\begin{array}{l}\text { Status Pengujian } \\
\text { input, edit dan hapus }\end{array}$ & Sukses $100 \%$ \\
\hline
\end{tabular}

Tabel 3. Pengujian input, edit dan delete data siswa

\begin{tabular}{ll|cc}
\hline No & Aktivitas & \multicolumn{2}{|c}{$\begin{array}{c}\text { Rata-rata waktu yang } \\
\text { dibutuhkan untuk } \\
\text { melakukan aktivitas para } \\
\text { responden }\end{array}$} \\
& & $\begin{array}{c}\text { Sebelum } \\
\text { Sesudah }\end{array}$ \\
\hline 1 & $\begin{array}{l}\text { Presensi per } \\
\text { siswa }\end{array}$ & 10,9 & 9,1 \\
\hline 2 & $\begin{array}{l}\text { Memberi } \\
\text { Poin } \\
\text { Hukuman }\end{array}$ & 6,3 & 1,2 \\
\hline 3 & $\begin{array}{l}\text { Membuat } \\
\text { Laporan }\end{array}$ & 10,0 & 5,5 \\
\hline Rata-rata & 17,4 & 6.9 \\
\hline
\end{tabular}

Pengujian pada tabel 1. menunjukkan bahwa admin dan user dapat masuk ke halaman utama apabila data mereka sudah terdaftar pada database.
Pada tabel 2. menunjukkan bahwa pengujian input untuk menambah data yang baru, semua form yang ada harus dipastikan terisi semua. Edit data siswa digunakan untuk menyesuaikan data terbaru (apabila terdapat perubahan data). Sedangkan untuk hapus data hanya bisa dilakukan saat awal proses tambah data.

Pada tabel 3. menunjukkan hasil bahwa terdapat selisih sekitar 4 menit 6 detik antara sebelum dan sesudah penggunaan sistem. Adanya peningkatan efisiensi pada saat memanfaatkan sistem presensi online dibandingkan dengan sebelumnya ditunjukkan pada tabel 3.3. pengujian ini dilakukan oleh beberapa Aktor, yaitu Aktivitas presensi (mencatat kehadiran siswa) dilakukan oleh 10 Siswa, aktivitas memberi poin hukuman dan membuat laporan dilakukan oleh Admin (pengelola data di sekolah) sejumlah 6 orang.

Implementasi sistem merupakan tahapan yang dilakukan setelah melakukan tahap perancangan sistem yaitu menjelaskan hasil yang diperoleh setelah 
sistem presensi online ini diimplementasikan. Penerapan sistem ini didukung oleh data kehadiran siswa yang telah diinputkan langsung oleh siswa yang bersangkutan dengan bagian Admin sekolah yang secara otomatis, hal ini menunjukkan data pendukung dimaksud dapat disediakan secara akurat.

Hasil dari penelitian ini adalah sistem presensi yang dijalankan pada perangkat komputer berbasis website, pada SMK Ma'arif.

\section{KESIMPULAN DAN SARAN}

Penerapan penelitian seputar Sistem Presensi Online dan Pemberian poin Hukuman di SMK Ma'arif NU berbasis Web, dapat disimpulkan bahwa dengan menggunakan sistem dimaksud dapat meminimalisir aktivitas pencatatan kehadiran siswa, pemberian poin hukuman dan pembuatan laporan menjadi lebih efektif dan efisien. Berdasarkan informasi yang diperoleh saat sistem diujikan, menunjukkan bahwa dengan sistem presensi yang

Sistem presensi online ini masih memiliki kekurangan yaitu proses input data masih menggunakan input type atau mengetik, oleh karena itu pada penelitian berikutnya diharapkan dapat mengembangkannya sehingga dapat meningkatkan kemudahan dalam mengoperasikannya.

\section{DAFTAR PUSTAKA}

Adani, M. R. (2018). Jenis Aplikasi Berbasis Web Beserta Contoh Penerapannya. sekawan media.

https://www.sekawanmedia.co.id/aplikasiberbasis-web/

Afrianto, I., \& Setiyadi, A. (2019). Sistem Informasi Monitoring Perdagangan Pariwisata Dan Investasi Di Indonesia Dengan NegaraNegara Di Kawasan Amerika Dan Eropa. Informatics for Educators and Professional, 3(2).

Ardianti, M. D. (2019). Pengaruh kualitas sarana fisik dan keaktifan siswa terhadap prestasi belajar siswa di SMA IT Asy-Syadzili [Thesis]. Universitas negeri Malang. http://repository.um.ac.id/id/eprint/80078

Fitrah, Y., S, W., \& Putra, D. S. (2021). Identifikasi Penyebab Rendahnya Intensitas Belajar Siswa. MSI Transaction on Education, 2(3), 139-148. https://doi.org/10.46574/mted.v2i3.64

Hanifah, U., Alit, R., \& Sugiarto. (2016). Penggunaan Metode Black Box Pada Pengujian Sistem Informasi Surat Keluar Masuk. XI(2).

Haryono, K., \& Asa Firdausi, F. A. (2017). Sistem Informasi Monitoring Wiraniaga Studi Kasus Di UD. Super Dangsul.

Mursyidah, M., \& Hidayat, H. T. (2018). Pengujian Sistem Informasi Akuntansi Biaya Operasional Sekolah Dengan Black Box
Testing. Jurnal Infomedia, 2(2). https://doi.org/10.30811/.v2i2.512

Setiyani, L. (2019). Pengujian Sistem Informasi Inventory pada perusahaan Distributor Farmasi Menggunakan Metode Black Box Testing. Techno Xplore: Jurnal Ilmu Komputer Dan Teknologi Informasi, 4(1), $1-9$.

https://doi.org/10.36805/technoxplore.v4i1. 539

Susanto, H., \& Sudiyatno. (2014). Data mining untuk memprediksi prestasi siswa berdasarkan sosial ekonomi, motivasi, kedisiplinan dan prestasi masa lalu. Jurnal Pendidikan Vokasi, 4(2), 222-231. https://doi.org/10.21831/jpv.v4i2.2547 